\title{
Determinants of Maritime Companies' Financial Performance in Contributing to the Indonesia Maritime Human Resource Development
}

\author{
Agus Budi Hartono ${ }^{1}$, Powell Gian Hartono ${ }^{2 *}$, Georgina Maria Tinungki ${ }^{3}$ \\ ${ }^{1}$ Department of Ship Mechanical Engineering, AMI Maritime Polytechnic, Makassar, Indonesia \\ ${ }^{2}$ Laboratory of Quantitative Analysis Instruments, Faculty of Economics and Business, Trisakti \\ University, Jakarta, Indonesia \\ ${ }^{3}$ Department of Statistics, Faculty of Mathematics and Natural Sciences, Hasanuddin University, \\ Makassar, Indonesia \\ *Corresponding author's e-mail: powell022167008@std.trisakti.ac.id
}

\begin{abstract}
This study examined factors that are assumed to influence the profitability of maritime companies as determinants of company performance in relation to the development of marine human resource development as stipulated in PP 47 of 2012 and PP 51 of 2012. Hypothesis testing was carried out to test the direction and significance of influence of formulated hypotheses The results showed that company age positively affect the profitability of maritime companies. Other factors that had been assumed to affect company profitability turned out to show no significant influences including company size, company growth, and capital structure. Maritime companies are recommended to take into account the managerial implications of this study, while the government is expected consider company size in formulating any regulation regarding PP 51 of 2012.
\end{abstract}

Keywords: Maritime Company Performance, Company Size, Company Growth, Capital Structure, Maritime Company, Company Age

\section{Introduction}

Indonesia is an archipelago country with 17,508 in which sea transportation dominates. The need for sea transportation facilitated by maritime companies including national and international maritime Indonesian water takes approximately $2 / 3$ of the total area of the Indonesia and it is the main factor contributing to the development of sea transportation in Indonesia. companies [1,2].

Maritime companies strongly contribute to Indonesian economy. For instance, the sub-sector of maritime industry, shipping industry develops well. The data obtained from the Directorate General of Sea Transportation of the Indonesian Ministry of Transportation, in 2017, there were 96 routes and 481 transit ports with a budget of IDR 943,922,000.000. In 2018 there the numbers increased to 113 routes and 498 transit ports with a total budget of IDR 1,102,000.000.000. of which 46 routes are under the management of PT. Pelayaran Nasional Indonesia (Persero), while the remaining 67 routes are under the management of private companies through public tenders [3].

Shipping industry shows positive business outlook on a national scale. Apart from its direct contribution to the transportation services for passengers and goods,

This paper is presented in The $4^{\text {th }}$ International Conference on Maritime Education and Training October $8^{\text {th }}$, 2020, Makassar, Indonesia 
shipping industry has an indirect role called multiplier effect. Economic activities are growing and developing rapidly as the need for sea transportation has been wellfacilitated by maritime companies [4].

The maritime industry is also supported by professional human resources who graduated from maritime science education and maritime training institutions in Indonesia, both state-owned schools and private ones. Maritime companies are also required to serve as service providers in the provision of professional human resources in the transportation sector, in this case sea transportation. This obligation is regulated in Government Regulation Number 51 of 2012 concerning Human Resources in the Field of Transportation, articles 44, 45, and 46 [5]. This requirement is also regulated in the Government Regulation Number 47 of 2012 concerning Social and Environmental Responsibility of Limited Liability Companies, in which it is stated that maritime companies are obliged to spare corporate social responsibility fund that can be allocated for the development of marine human resources [6]. The corporate social responsibility fund is spared from net profit [7].

Company performance determines the contribution of corporate social responsibility of a company. Company performance can be measured by company profitability. .[8] Company profitability is defined as the company's ability to generate profit, in which profit ensures the sustainability of a company.

Profitability is defined as company's ability to generate high net income from business activities. Company profitability reflects the performance of a company. A company with strong profitability is said to have good performance, in which company performance refers to company's ability to generate net income, vice versa. Profitability in this study were measured based on return on assets ratio. The return on assets ratio illustrates how the profitability of a company optimizes company's assets [9]. Some determinants were assumed to affect company profitability as a measure of company performance, including company size, company growth, capital structure or financial leverage, and company age [10-12].

Company size is the size of a company measured in certain measurement unit. Bigger company size is closely related to greater profit. Company size can be measured based on company's total assets. Total assets describe the overall assets owned by a company. The greater the company's assets, the bigger its business activities that will generate greater profits. The proxy for measuring firm size is the natural logarithmic transformation of the firm's total assets [9,10.13]. The results of a research [14] showed that company size has a positive influence on profitability, while [10] found that company size affects company profitability.

Company growth shows the development of a company over time. Companies that have positive growth are known to have greater ability to generate high profits. The trend of company growth measures the outlook of company growth, whether the outlook is positive or negative. Company growth can be measured by the value of revenue growth of current year's and previous year's revenue. Stronger company growth positively affects company profitability $[15,16]$. The results of a research done by [17] indicated the positive influence of company growth on profitability.

Capital structure is the comparison of the proportion of liabilities and equity in the form of company's assets. Company's assets are usually obtained from liabilities and equity. Hence, the capital structure of liabilities and equity will affect profitability and the dimension of capital structure is measured based on debt to equity ratio. Greater debt to equity ratio, which indicates bigger proportion of liabilities or debt to equity in company's assets, tends to be followed by smaller net profit. Bigger debt will charge a company with

This paper is presented in The $4^{\text {th }}$ International Conference on Maritime Education and Training 91 October $8^{\text {th }}$, 2020, Makassar, Indonesia 
interest costs on debt from cash flows which will reduce the net profit. Thus, debt to equity ratio has a negative influence $[12,14]$. The results of research conducted by $[13,14]$ indicated that capital structure or financial leverage negatively affects profitability.

Company age refers to the length of time a company exists. Older companies are assumed to have better business experience, and they are likely to generate greater profits and greater profitability. Company age was calculated using the squared logarithmic transformation of company age [11,18]. A research conducted by [11] showed that company age has a positive influence on profitability.

This current study examined the influence of factors assumed to affect company profitability, namely company size, company growth, capital structure or financial leverage, and company age. The population of this study were companies engaging in maritime industry sector listed on the Indonesia Stock Exchange between 2013 - 2018.

\begin{tabular}{|l|l|c|}
\hline \multicolumn{1}{|c|}{ Independent Variable } & & Dependent Variable \\
\cline { 1 - 1 } Company Size & & \\
\hline Company Growth & Profitability \\
\hline $\begin{array}{l}\text { Capital Structure or financial } \\
\text { leverage }\end{array}$ & \\
\hline Company Age & \\
\hline
\end{tabular}

Figure 1. Conceptual Framework

Based on the conceptual framework of this study, hypotheses were proposed as follows. $\mathrm{H}_{1}$ : Company size has a positive and significant influence on profitability.

$\mathrm{H}_{2}$ : Company growth has a positive and significant influence on profitability.

$\mathrm{H}_{3}$ : Capital structure or financial leverage has a negative and significant influence on profitability.

$\mathrm{H}_{4}$ : Company Age has a positive and significant influence on profitability.

\section{Research Method}

Hypothesis testing was carried out to test the direction and significance of influence of formulated hypotheses [19].The data were obtained using panel data collection regarding maritime companies listed on the Indonesia Stock Exchange (IDX) for 6 years from 2013 - 2018. Panel data regression with a common effect model, fixed effect approach and random effect model were employed as the data analysis tools [20]. The date obtained were then processed using the e-views program version 10 and SPSS version 22.

Table 1. Variables and Measurements

\begin{tabular}{|c|c|c|c|}
\hline Variable & Dimension & Formulation & Source \\
\hline Profitability & $\begin{array}{l}\text { Return on Assets } \\
(R O A)\end{array}$ & $R O A=\frac{\text { Earning After Tax }}{\text { Total Assets }}$ & {$[10,21,22]$} \\
\hline Company Size & Size (Size) & $\begin{array}{l}\text { SIZE } \\
=\text { natural logaritm of total assets }\end{array}$ & [10.21] \\
\hline Company Growth & $\begin{array}{l}\text { of } \\
\text { ce }(\mathrm{GR})\end{array}$ & $G R=\frac{\text { Revenue }_{t}-\text { Revenue }_{t-1}}{\text { Revenue }_{t-1}}$ & {$[10.21]$} \\
\hline $\begin{array}{l}\text { Capital Structure } \\
\text { or Financial } \\
\text { Leverage }\end{array}$ & $\begin{array}{l}\text { Debt to Equity } \\
\text { Ratio }(D E R)\end{array}$ & $D E R=\frac{\text { Total Liabilities }}{\text { Total Equity }}$ & {$[14,21]$} \\
\hline Company Age & $\begin{array}{l}\text { Company Age } \\
(A G E)\end{array}$ & $\begin{array}{l}\text { AGE } \\
=\text { the square of logarithm of age }\end{array}$ & {$[17,21,23]$} \\
\hline
\end{tabular}

This paper is presented in The $4^{\text {th }}$ International Conference on Maritime Education and Training 92 October $8^{\text {th }}$, 2020, Makassar, Indonesia 
Purposive sampling method [19] was administered to select maritime companies as samples. Only companies that met the predetermined criteria were selected including the conformity to the specified research period, companies that were not within delisting process and had complete financial reports. A total of 11 companies were sampled in this study as described in the following table:

Table 2. Samples of this Study

\begin{tabular}{rc}
\hline \multicolumn{1}{c}{ Company } & IDX Code \\
\hline Paya, Tbk & BBRM \\
PT Berlian Maju Tanker, Tbk & BLTA \\
PT Buana Lintas Lautan, Tbk & BULL \\
PT Logolindo Samudramakmur, Tbk & LEAD \\
PT Mitrabahtera Segara Sejati, Tbk & MBSS \\
PT Pelayaran Nelly Dwi Putri, Tbk & NELY \\
PT Indo Straits, Tbk & PTIS \\
PT Samudera Indonesia, Tbk & SMDR \\
PT Pelayaran Tempuran Emas, Tbk & TMAS \\
PT Trans Power Marine, Tbk & TPMA \\
PT WInterar Offshore Marine, Tbk & WINS
\end{tabular}

The panel data regression model using the common effect model, fixed effect model, and random effect model require several tests to determine the appropriate model. The tests included Chow test and the Hausman test. The chow determined which model was suitable for either common effect model or the fixed effect model.

The chow test using e-views version 10 resulted in the $\mathrm{p}$-value of the Chi-square cross-section of $0.0000<5 \%$, indicating that the fixed effect model was the appropriate model. After that, the Hausman test was carried out to determine which model was suitable for either fixed effect model or random effect model.

The Hausman test using e-views version 10 obtained a p-value of the random cross-section of $0.0000<5 \%$. Hence, the fixed effect model was the appropriate model. Since both Chow test and the Hausman test showed the fixed effect model as the most appropriate model, it was not considered necessary to administer Lagrange Multiplier test. After that, the coefficient of determination test was determined.

The determination coefficient obtained from the fixed effect model using eviews version 10 by adjusted R-square value was 0.673812 or $67.3812 \%$. These results indicate that this study explained $67.3812 \%$ of the variation of Company Size, Company Growth, Capital Structure or financial leverage, and Company Age on the profitability of maritime companies. Whilst, the rest $32.6188 \%$ was affected by other variables that were not included in this study. The coefficient value of $67.3812 \%$ was considered macro to be generalized to the population in this study. Furthermore, a global test or a simultaneous test was carried out on the panel data regression model of this study.

The F test or global test or simultaneous test using e-views version 10 for the fixed effect model resulted in F-statistic value of 4.098576 with the p-value of the Fstatistic of $0.033985<0.05$. These results indicated that the null hypothesis stating the absence of simultaneous influence of Company Size, Company Growth, Capital Structure or financial leverage, and Company Age have no effect on the profitability of

This paper is presented in The $4^{\text {th }}$ International Conference on Maritime Education and Training 
maritime companies was rejected. Thus, alternative hypothesis was used, in which at least 1 (one) independent variable has a significant effect on the profitability of maritime companies as the dependent variable.

The data analysis model in this study produced a panel data regression equation as follows:

Di mana:

$$
R O A_{i t}=\beta_{0}+\beta_{1} S I Z E_{i t}+\beta_{2} G R_{i t}+\beta_{3} D E R_{i t}+\beta_{4} A G E_{i t}+\varepsilon_{i t}
$$

ROA $\quad$ : return on assets at $i, t$.

SIZE $\quad$ : Company Size at $i, t$.

$G R_{i t} \quad:$ growth of revenue at $i, t$.

$D E R_{\text {it }} \quad:$ debt to equity ratio at $i, t$.

$A G E_{i t} \quad$ : Company Age at $i, t$.

$\beta_{0} \quad$ : constant of the regression model.

$\beta_{1}, \beta_{2}, \beta_{3}, \beta_{4} \quad$ : coefficient of each independent variable.

$\varepsilon_{i t} \quad:$ residual coefficient of the regression model at $i, t$.

\section{Results and Analysis}

\subsection{Descriptive Statistic}

Descriptive Statistics

\begin{tabular}{|l|r|r|r|r|r|}
\hline & N & Minimum & Maximum & \multicolumn{1}{|c|}{ Mean } & \multicolumn{1}{|r|}{ Std. Deviation } \\
\hline ROA & 77 & -.40109 & 1.57162 & .0116757 & .20586574 \\
SIZE & 77 & 12.92266 & 16.11001 & 14.6037356 & .87943708 \\
GR & 77 & -.91360 & 1.18186 & .0401973 & .32323463 \\
DER & 77 & -1.71501 & 3.96801 & 1.0171716 & .83185743 \\
AGE & 77 & .91058 & 3.05616 & 1.9813919 & .55343795 \\
Valid N (listwise) & 77 & & & & \\
\hline
\end{tabular}

Figure 2. Descriptive Statistics

The results of descriptive statistics using SPSS version 22 as presented in Figure 2 above show the mean value, standard deviation, highest value and lowest value. Highest profitability with the highest return on assets (ROA) proxy was obtained by PT Berlian Maju Tanker, Tbk in 2015, while the lowest one was found in PT Pelayaran Nasional Bina Buana Raya, Tbk in 2019. Whilst, profitability as proxied by ROA obtained an average value of 0.0116757 with a standard deviation of 0.20586574 . The highest Company Size with a natural logarithmic transformation proxy for the company's total assets was shown by PT Berlian Maju Tanker, Tbk in 2013, while the lowest one was in PT Pelayaran Nelly Dwi Putri, Tbk in 2016. The average and standard deviation values for Company Size were 14.6037356 and 0.87943708 .

PT Logolindo Samudramakmur, Tbk had Company Growth rate proxied for current income growth against the previous period, while the lowest Company Growth was found in PT Berlian Maju Tanker, Tbk in 2016. The average and standard deviation value for Company Growth was 0.0401973 and 0.32323463 . The capital structure or financial leverage with the highest debt to equity ratio (DER) proxy was found in PT Pelayaran Tempuran Emas, Tbk in 2013, and the lowest one in PT Berlian Maju Tanker, Tbk in 2013. Average value and standard deviation for the comparison level between liabilities and equity of maritime companies were 1.0171716 and 0.83185743 respectively.

This paper is presented in The $4^{\text {th }}$ International Conference on Maritime Education and Training 94 
The oldest company proxied for quadratic logarithmic transformation to Company Age was shown by PT Samudera Indonesia, Tbk in 2019 of 56 years. While the youngest ones were PT Buana Lintas Lautan, Tbk and PT Trans Power Marine, Tbk in 2019 of aged 15 years. The mean and standard deviation of Company Age with these proxies were 1.9813919 and 0.55343795 respectively.

\subsection{Partial Test and Discussions on Results of this Study}

Table 3. Results of Panel Data Regression using Fixed Effect Model

\begin{tabular}{|l|r|r|r|c|}
\hline \multirow{2}{*}{$\begin{array}{c}\text { Proxied Independent } \\
\text { Variable }\end{array}$} & \multicolumn{4}{|c|}{$\begin{array}{c}\text { Dependent Variable: Dividend Policy } \\
\text { Proxied by } \\
\text { Return on Assets }\end{array}$} \\
\cline { 2 - 5 } & Coefficient & $\begin{array}{c}\text { p-value } \\
\text { (two-tailed) }\end{array}$ & $\begin{array}{c}\text { p-value } \\
\text { (one-tailed) }\end{array}$ & $\begin{array}{c}\text { Decision } \\
(\boldsymbol{\alpha}=\mathbf{5 \%})\end{array}$ \\
\hline Constant & -8.131957 & 0.1877 & 0.0938 & ----- \\
\hline Size & 0.213669 & 0.5093 & 0.2547 & Accepted \\
\hline Growth & -0.299706 & 0.0664 & 0.0332 & Rejected \\
\hline Debt to Equity Ratio & -0.373263 & 0.0746 & 0.0373 & Rejected \\
\hline AGE & 2.681734 & 0.0107 & 0.0054 & Rejected \\
\hline
\end{tabular}

From table 3, the equation of panel data regression used in this study was:

$$
R O A=-8,131967+0,213669 S I Z E-0,299706 \text { GR }+0,373263 \text { DER }
$$

\section{$+2,681734 A G E$}

$\mathrm{H}_{1}$ : Company Size has a positive and significant influence on Profitability .

The panel data regression using the fixed effect model showed a coefficient and $\neg$ p-value of 0.213669 and 0.5093 respectively. Therefore, the coefficient supports the the formulated hypothesis as it shows positive direction, yet the significance value of $0.5093 / 2=0.25465>5 \%$, rejects the H1. Similar results were found by $[13,15,17]$ in which Company Size was not proven influential to company profitability. Hence, Company Size does not determine the profitability in the evaluation of company performance. Larger the company size is followed by higher costs for operational activities, such as allocations for labor, general administrative costs, maintenance of buildings, ships, machines, equipment, and it does not significantly increase the profits, even it might reduce the profitability [15].

$\mathrm{H}_{2}$ : Company Growth has a positive and significant influence on Profitability

For the fixed effect model, the coefficient and p-value were found at -0.299706 and 0.0664 , indicating positive direction, yet the significance value was regarded small at $0.0664 / 2=0.0332<5 \%$ to reject $\mathrm{H} 2$. Likewise, [14-16] also found that Company Size does not influence company profitability. Basically, greater revenue measures the company growth. However, growth occurred, yet company assets and costs such as salary, wages, and company operational costs increased as well. Thus, Company Growth does not affect profitability.

$\mathrm{H}_{3}$ : Capital Structure or financial leverage has a negative and significant influence on

Profitability.

The panel data regression for the fixed effect model showed a coefficient and pvalue of 0.373263 and 0.0746 . These results indicate that the coefficient was not in line

This paper is presented in The $4^{\text {th }}$ International Conference on Maritime Education and Training 
with the formulated hypothesis at negative direction. Although its significance value reached $0.0746 / 2=0.0373<5 \%$, H3 was rejected. Similarly, [24],found capital structure non-influential to profitability. Capital structure was reflected on the ratio of liabilities to equity does not affect company profitability. Therefore, assumption that greater debt ratio is normatively followed by increases in profitability was proven untrue. Instead, it increased the level of company profitability [12,14,24].

$\mathrm{H}_{4}$ : Company Age has a positive and significant influence on Profitability.

The coefficient and p-value the fixed effect model was 2.681734 and 0.0107 respectively. These values supports the positive direction as formulated in the hypotheses. The significance value of $0.0107 / 2=0.0054<5 \%$, was adequate to accept H3. Similar result was also found by [11], in which Company Age was proven to share a positive and significant influence on company profitability. In the context of maritime companies, it is evident that older company would lead to higher profit. This proves that Company Age positively correlates to the performance of maritime companies $[11,17,18,25]$.

\section{Conclusion}

Out of four variables assumed to determine company profitability as a measurement of the performance of maritime companies under study, only Company Age was found to share a positive and significant influence. Whereas, other variables including Company Size, Company Growth, and capital structure in the form of a ratio of debt to equity did not show significant influence on company profitability as a measurement of company performance.

The managerial implication proposed in this study is directed for companies, in which it is suggested that dividends should be distributed to maintain company's managerial functions in various aspects. Regarding financial managerial function, companies are expected to be more attentive to financial ratios, especially the ones included in the rejected hypotheses. Most of them shared the opposite direction even though the significances were strong enough as they were smaller than the level of risk of lesser than $5 \%$.

For the human resource development in the field off marine transportation, it is necessary to set clear regulations regarding the contribution of maritime companies in developing marine human resources as regulated in Government Regulation No. 51 of 2012 concerning Human Resources in the Field of Transportation, articles 44, 45, and 46. The results of this study contribute to the formulation and enactment of regulations related to the contribution obligations of shipping companies. Company Age should be taken into account. Older companies were expected to bring greater contribution to the development of marine human resources in Indonesia [5]. This is also regulated in Government Regulation no. 47 of 2012 concerning Social and Environmental Responsibility of Limited Liability Companies, in which the company in this case is the maritime industry that is obliged to provide corporate social responsibility fund to be allocated to the development of human resource of this sector.

The limitations of this study were related to unavailability of financial reports of maritime companies. In addition, the number of companies included in this study was not quite large that statistically, the data normality is assumed to be not as good as if larger sample and population were included.

This paper is presented in The $4^{\text {th }}$ International Conference on Maritime Education and Training 96 
Suggestions are directed to companies, in which companies are strongly recommended to take into account the managerial implications of this study. The government, which in the context of this study refers to the regulators in the field of marine human resource development, is expected to put Company Age into consideration regarding the contribution of maritime companies in developing human resources. At last, future researchers are encouraged to conduct studies on factors affecting the performance of maritime companies to support the human resource development through more comprehensive research.

\section{References}

[1] Kadarisman M. Kebijakan Keselamatan Dan Keamanan Maritim Dalam Menunjang Sistem Transportasi Laut. J Manaj Transp Dan Logistik. 2017;4(2):177.

[2] Ardiansyah A. Pembakuan Nama Pulau di Indonesia Sebagai Upaya untuk Menjaga Kedaulatan Negara Republik Indonesia. Pandecta Res Law J. 2013;6(2).

[3] Yulianto A. Pelayaran Perintis Dukung Pertumbuhan. Republika.co.id. 2020 Oct;

[4] Wijaya A, Dewanti Lestari. Prospek industri pelayaran nasional di 2019. ANTARA. 2019;

[5] Pemerintah-RI. PERATURAN PEMERINTAH REPUBLIK INDONESIA NOMOR 51 TAHUN 2012 TENTANG SUMBER DAYA MANUSIA DI BIDANG TRANSPORTASI. Sekretariat Negara Republik Indonesia, 51 Indonesia; 2012.

[6] Pemerintah-RI. PERATURAN PEMERINTAH REPUBLIK INDONESIA NOMOR 47 TAHUN 2012 TENTANG TANGGUNG JAWAB SOSIAL DAN LINGKUNGAN PERSEROAN TERBATAS. Sekretariat Negara Republik Indonesia, 47 Indonesia; 2012.

[7] Sari WR, Matusin AR. Net Income and CSR Disclosure as Predictors Shares Price and Return per Share. J Din Manaj. 2019;10(1):81-91.

[8] Putri RA, Christiawan YJ. Pengaruh Profitabilitas, Likuiditas, dan Leverage terhadap pengungkapan Corporate Social Responsibility. Bus Account Rev. 2014;2(1):2014.

[9] Sari MRPA, Handayani N. Pengaruh Profitabilitas, Ukuran Perusahaan Dan Leverage, Terhadap Nilai Perusahaan Transportasi. J Ilmu dan Ris Akunt. 2016;5(9):1-18.

[10] Meidiyustiani R. Pengaruh Modal Kerja, Ukuran Perusahaan, Pertumbuhan Penjualan, Dan Likuiditas Terhadap Profitabilitas Pada Perusahaan Manufaktur. J Akunt dan Keuang [Internet]. 2016;5(2):131-43. Available from: http://ejournal.atmajaya.ac.id/index.php/JM/article/view/95

[11] Harahap N, Harmain H, Siregar S, Nova Maharani. PENGARUH ISLAMIC SOCIAL REPORTING (ISR), UMUR PERUSAHAAN DAN KEPEMILIKAN SAHAM PUBLIK TERHADAP PROFITABILITAS (ROA) PADA PERUSAHAAN YANG TERDAFTAR DI JAKARTA ISLAMIC INDEX (JII) TAHUN 2010-2014. KITABAH. 2017;1(1):69-91.

[12] Iskandar T, DP EN, Darlis E. Pengaruh Perputaran Modal Kerja, Struktur Modal Dan Likuiditas Terhadap Profitabilitas Perusahaan Industri \& Chemical di Bursa Efek Indonesia. J Online Mhs Fak Ekon Univ Riau. 2014;1(2):1-15.

[13] Ratnasari L, Budiyanto. PENGARUH LEVERAGE, LIKUIDITAS, UKURAN PERUSAHAAN TERHADAP PROFITABILITAS PADA PERUSAHAAN

This paper is presented in The $4^{\text {th }}$ International Conference on Maritime Education and Training 
OTOMOTIF DI BEI. J Ilmu dan Ris Manaj. 2016;5(6):1-15.

[14]Rifai M, Arifati R, Magdalena M. Pengaruh Ukuran Perusahaan, Struktur Modal Dan Pertumbuhan Perusahaan Terhadap Profitabilitas Studi Pada Perusahaan Manufaktur Di Bei Tahun 2010-2012. J Ilm Mhs S1 Akunt Univ Pandanaran. 2015;1(1):1-8.

[15] Putra AAWY, Badjra IB. Pengaruh Leverage, Pertumbuhan Penjualan Dan Ukuran Perusahaan Terhadap Profitabilitas. E-Jurnal Manaj Univ Udayana. 2015;4(7):2052-67.

[16] Miswanto, Abdullah YR, Suparti S. Pengaruh Efisiensi Modal Kerja, Pertumbuhan Penjualan Dan Ukuran Perusahaan Terhadap Profitabilitas Perusahaan. J Bisnis dan Ekon. 2017;24(2):119-35.

[17]Novyanny MC, Turangan JA. Pengaruh Likuiditas, Ukuran Perusahaan, Umur Perusahaan Dan Pertumbuhan Perusahaan Terhadap Profitabilitas Pada Perusahaan Jasa Terdaftar Pada Bursa Efek Indonesia. J Manag Stud. 2017;4(1):66-78.

[18] Muchtar S, Hartono PG, Sari WR. The Effect of Corporate Governance on Sharia Corporate Performance in Indonesia. In: Advances in Economics, Business and Management Research. 2020. p. 192-6.

[19] Sekaran U, Bougie R. Reserach Methods for Bussiness A Skill-Bulding Approach. 7th ed. London: John Wiley \& Sons; 2016. 1-447 p.

[20] Gujarati DN, Porter DC. Basic Econometrics. 5th ed. Boston, Mass: McGraw-Hill; 2011.

[21]Zutter CJ, Smart SB. Principles of Managerial Finance. 15th ed. London: Pearson; 2019.

[22] Hartono PG, Lestari HS, Wijaya R, Hartono AB, Tinungki GM. LIKUIDITAS SEBAGAI PREDIKTOR PROFITABILITAS: Sebuah Studi Empiris pada Perusahaan Sektor Industri Manufaktur. Deriv J Manaj. 2020;14(2).

[23] Hartono PG, Matusin AR. The Determinants of Dividend Policy on Real Estate, Property, and Building Construction Companies Listed in IDX using Unbalanced Panel Data Approach. Int J Appl Bus. 2020;4(1).

[24] Wibowo A, Wartini S. Efisiensi Modal Kerja, Likuiditas dan Leverage Terhadap Profitabilitas Pada Perusahaan Manufaktur Di BEI. J Din Manaj. 2012;3(1):49-58.

[25] Hartono PG, Matusin AR. Faktor-Faktor Penentu Kebijakan Dividen Perusahaan Real Estate dan Property yang Terdaftar di BEI tahun 2013 - 2019. Faculty of Economics and Business, Trisakti University; 2020. 